Marquette University

e-Publications@Marquette

Physics Faculty Research and Publications

Physics, Department of

11-1-2008

Trapping and Characterization of a Reaction Intermediate in Carbapenem Hydrolysis by B. cereus Metallo- $\beta$-lactamase

Mariana F. Tioni

Universidad Nacional de Rosario

Leticia 1. Llarrull

University of Notre Dame

Andrés A. Poeylaut-Palena

Universidad Nacional de Rosario

Marcelo A. Martí

Universidad de Buenos Aires (UBA)

Miguel Saggu

Technische Universitat Berlin

See next page for additional authors

Accepted version. Journal of the American Chemical Society, Vol. 130, No. 47 (November 2008): 15852-15863. DOI. (C) 2008 American Chemical Society. Used with permission.

Brian Bennett was affiliated with Medical College of Wisconsin at the time of publication. 


\section{Authors}

Mariana F. Tioni, Leticia 1. Llarrull, Andrés A. Poeylaut-Palena, Marcelo A. Martí, Miguel Saggu, Gopal R. Periyannan, Ernesto G. Mata, Brian Bennett, Daniel H. Murgida, and Alejandro J. Vila 


\title{
Trapping and Characterization of a Reaction Intermediate in Carbapenem Hydrolysis by B. cereus Metallo- $\beta$-lactamase
}

\author{
Mariana F. Tioni \\ IBR-CONICET and Biophysics Section, \\ Universidad Nacional de Rosario \\ Leticia I. Llarrull \\ IBR-CONICET and Biophysics Section, \\ Universidad Nacional de Rosario \\ Department of Chemistry and Biochemistry, \\ University of Notre Dame, \\ Notre Dame, IN \\ Andrés A. Poeylaut-Palena \\ IQUIR-CONICET, \\ Universidad Nacional de Rosario \\ Marcelo A. Martí \\ Universidad de Buenos Aires \\ Miguel Saggu \\ Technische Universität Berlin
}


NOT THE PUBLISHED VERSION; this is the author's final, peer-reviewed manuscript. The published version may be accessed by following the link in the citation at the bottom of the page.

\author{
Gopal R. Periyannan \\ Medical College of Wisconsin, \\ Milwaukee, WI \\ Ernesto G. Mata \\ IQUIR-CONICET, \\ Universidad Nacional de Rosario \\ Brian Bennett \\ Medical College of Wisconsin, \\ Milwaukee, WI \\ Daniel H. Murgida \\ Universidad de Buenos Aires \\ Alejandro J. Vila \\ IBR-CONICET and Biophysics Section, \\ Universidad Nacional de Rosario
}

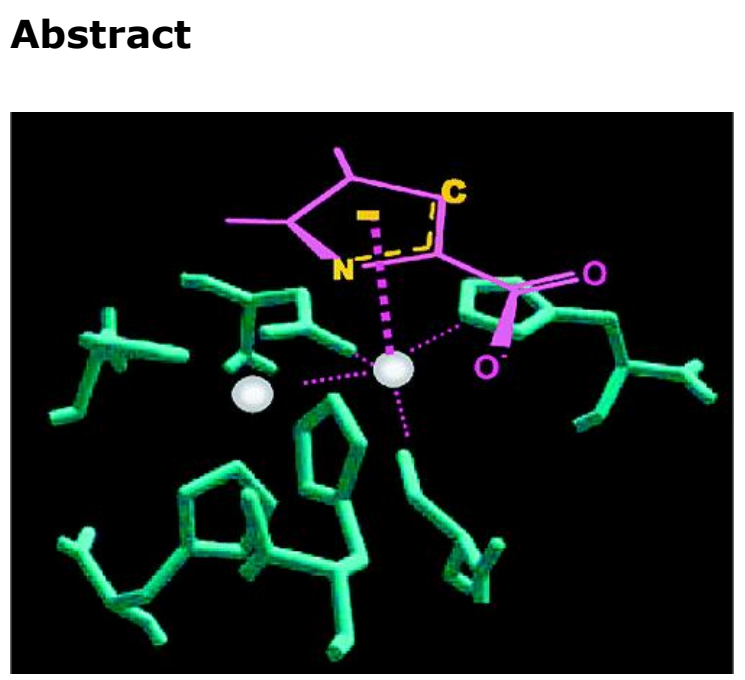

Metallo- $\beta$-lactamases hydrolyze most $\beta$-lactam antibiotics. The lack of a successful inhibitor for them is related to the previous failure to characterize a reaction intermediate with a clinically useful substrate. Stopped-flow experiments together with rapid freeze-quench EPR and Raman spectroscopies were used to characterize the reaction of Co(II)-BcII with imipenem. These studies show that $\mathrm{Co}$ (II)-BcII is able to hydrolyze imipenem 
in both the mono- and dinuclear forms. In contrast to the situation met for penicillin, the species that accumulates during turnover is an

enzyme-intermediate adduct in which the $\beta$-lactam bond has already been cleaved. This intermediate is a metal-bound anionic species with a novel resonant structure that is stabilized by the metal ion at the $\mathrm{DCH}$ or $\mathrm{Zn} 2$ site. This species has been characterized based on its spectroscopic features. This represents a novel, previously unforeseen intermediate that is related to the chemical nature of carbapenems, as confirmed by the finding of a similar intermediate for meropenem. Since carbapenems are the only substrates cleaved by B1, B2, and B3 lactamases, identification of this intermediate could be exploited as a first step toward the design of transition-state-based inhibitors for all three classes of metallo- $\beta$-lactamases.

\section{Introduction}

$\beta$-Lactamases constitute the most important bacterial defense mechanism against the three major groups of $\beta$-lactam antibiotics currently available in the pharmaceutical industry: penicillins, cephalosporins, and carbapenems. ${ }^{1-3}$ These enzymes hydrolyze the $\beta$ lactam ring of these antibiotics, rendering them ineffective toward their bacterial targets. Metallo- $\beta$-lactamases (M $\beta L s)$ comprise a subgroup of $\beta$-lactamases, namely, Class B. ${ }^{4-6}$ In contrast to the better and longer known serine- $\beta$-lactamases (constituting Classes $A, C$, and D) that rely on a serine residue for activity, $M \beta L s$ require $\mathrm{Zn}$ (II) for function and display a different catalytic mechanism. Thus, M $\beta$ Ls are insensitive to the mechanism-based inhibitors that have proved clinically useful against serine- $\beta$-lactamases. Even more, M $\beta$ Ls have a broader substrate spectrum; many of them are plasmid-encoded and have therefore spread widely in recent years. These features make them a particularly worrisome clinical threat and turn their characterization into a subject of utmost relevance.

MßLs have been divided into subclasses B1, B2, and B3 based on sequence homology, metal ion requirements, and substrate profile. ${ }^{7,8}$ B2 lactamases are exclusive carbapenemases, and their active form is the mononuclear enzyme, while binding of a second metal ion is inhibitory. ${ }^{9-13} \mathrm{~B} 1 \mathrm{M} \beta \mathrm{Ls}$ have a broader substrate spectrum that also includes penicillins and cephalosporins ${ }^{14}$ and have been suggested to be active in both the mono- and dinuclear forms. ${ }^{15-20}$ B3 $M \beta L S$, in turn, have long been believed to be exclusively dinuclear ${ }^{21-25}$ but a new class B3 M $\beta L$ that is active in its mononuclear form (GOB) has been recently reported. ${ }^{26}$ This disparate behavior regarding metal 
ion requirement and substrate preferences has precluded simple generalizations on $\mathrm{M} \beta \mathrm{L}$ activity to be enunciated and inspired the proposal of different mechanisms of catalysis. This, in turn, suggests that a diverse portfolio of inhibitors may be needed to attain the clinically desirable goal of targeting each of the different classes of MßLS.

A remarkable feature of $M \beta L s$ is their ability to hydrolyze carbapenems. These $\beta$-lactam compounds not only act as antibiotics by inactivating the common $\beta$-lactam bacterial targets but they also behave as irreversible inhibitors of most serine- $\beta$-lactamases. ${ }^{27,28}$ For that reason, their use in clinical treatments is reserved as a last line of defense against bacterial strains that exhibit resistance to other $\beta$ lactams. As MBLs do not share structural features with their serine counterparts and operate through a completely different chemical mechanism, it is not surprising that they are not inactivated by inhibitors useful for serine- $\beta$-lactamases.

Most MBLs (and all the plasmid-encoded ones) fall within subclass B1 lactamases. Therefore, we concentrated our efforts on the study of the $B$. cereus enzyme, BcII, a prototypical B1 M $\beta L$. Since the native metal ion, $\mathrm{Zn}(\mathrm{II})$, is silent to most spectroscopic techniques, we employed $\mathrm{Co}$ (II) substitution to follow the reaction during turnover. ${ }^{12,25,29-31}$ This strategy provided evidence for the existence of two metal binding sites in BcII: one is tetrahedrally coordinated to three histidines and a water/hydroxide molecule ( $3 \mathrm{H}$ site), and the other has a bipyramidal geometry with the ligands being a cysteine, an aspartic acid, a histidine, and two water/hydroxide molecules (DCH site). ${ }^{18}$ The recent description of the details of the complex nature of metal ion binding by $\mathrm{BCII}^{32}$ and the prescient warning regarding future possible application of an adaptive pressure on pathogenic bacteria that are currently susceptible to the antibiotic effects of carbapenems ordain that a re-examination of the mechanism of action of BcII is both necessary and timely.

In the accompanying article we demonstrated that both monoand di-Co(II) BcII are active and that an equilibrium between two monometallated forms shifts upon substrate binding, favoring the $\mathrm{DCH}$ site during penicillin hydrolysis. ${ }^{55}$ In the present study, different time- 
resolved and rapid freeze-quenched spectroscopies were used to characterize the reaction of Co(II)-BcII with imipenem. This allowed us to identify and characterize a metal-bound anionic intermediate that accumulates during turnover with a novel resonant structure, which suggests new inhibitory strategies that might be targetted to all MßLs.

\section{Experimental Procedures}

\section{Reagents}

All chemicals were of the best quality available. Stock solutions of imipenem were prepared in $100 \mathrm{mM}$ Hepes pH 7.5, $200 \mathrm{mM} \mathrm{NaCl}$. Tetrahydrofuran (THF) was dried over sodium metal/benzophenone ketyl under dry nitrogen, distilled, and stored in a Schlenk bottle. Triethylamine (TEA) was dried over $\mathrm{KOH}$, distilled, and stored in a Schlenk bottle. All glass material was oven dried or dried under high vacuum (depending on the case) and purged with dry nitrogen.

\section{Enzyme Preparation}

Expression and purification of recombinant BcII were performed as reported previously. ${ }^{32}$ Enzyme purity was checked by SDS-PAGE and Coomassie staining. Protein concentration was determined spectrophotometrically using $\varepsilon_{280}=30500 \mathrm{M}^{-1} \cdot \mathrm{cm}^{-1} \cdot{ }^{15}$ Protein samples used were made metal free by extensive dialysis against $10 \mathrm{mM}$ Hepes $\mathrm{pH}$ 7.5, $20 \mathrm{mM}$ EDTA, $200 \mathrm{mM} \mathrm{NaCl}$ (two changes) followed by three exchanges in $10 \mathrm{mM}$ Hepes $\mathrm{pH} 7.5,1 \mathrm{M} \mathrm{NaCl}$, two in $10 \mathrm{mM}$ Hepes $\mathrm{pH}$ 7.5, $200 \mathrm{mM} \mathrm{NaCl}$, and one in $100 \mathrm{mM}$ Hepes pH 7.5, $200 \mathrm{mM} \mathrm{NaCl}$. All buffer solutions used to prepare the apoenzyme were treated by extensive stirring with Chelex 100 (Sigma) to eliminate traces of divalent metal ions. All dialysis steps were carried out at $4{ }^{\circ} \mathrm{C}$. Metal removal in apoprotein samples was verified using the colorimetric agent PAR [4-(2-pyridylazo)resorcinol] for divalent metal detection. ${ }^{33}$

Preparation of Co(II) derivatives of BcII was carried out as described previously. ${ }^{32}$ Effective Co(II) uptake was monitored by electronic absorption spectroscopy during titration of apo-BcII with $\mathrm{CoSO}_{4}$. Spectra were recorded at room temperature in a JASCO V-550 spectrophotometer using $1 \mathrm{~cm}$ path length quartz cuvettes. 
NOT THE PUBLISHED VERSION; this is the author's final, peer-reviewed manuscript. The published version may be accessed by following the link in the citation at the bottom of the page.

\section{Stopped-Flow Experiments}

Experiments were carried out on an SX.18-MVR stopped-flow spectrometer associated with a PD.1 photodiode array (Applied Photophysics, Surrey, U.K.). The sequence of electronic absorption spectra of Co(II)-substituted BcII upon reaction with imipenem was recorded on a logarithmic time scale with an integration time of 1.28 ms (typically 500 spectra in $50 \mathrm{~s}$ ). The path length of the cell was 1 $\mathrm{cm}$. Reactions were performed in $100 \mathrm{mM}$ Hepes pH 7.5, $200 \mathrm{mM}$ $\mathrm{NaCl}$, and the whole sample unit was kept at $6^{\circ} \mathrm{C}$ using a Lauda RC6 thermostatted circulator. Protein concentration in the syringe was 166 $\mu \mathrm{M}$, while imipenem concentrations were in the millimolar range.

\section{Kinetic Analysis of the Stopped-Flow Data}

Nonlinear regression analysis was used to fit single-wavelength traces with the program Dynafit (Biokin). ${ }^{34}$ Groups of data corresponding to hydrolysis of different concentrations of imipenem with BcII substituted with $0.6,1.0$, or $2.0 \mathrm{Co}$ (II) equivalents were fitted simultaneously. The concentrations of the different metal-loaded species initially present in the syringe were calculated based on the concentration of enzyme capable of binding metal and on the dissociation constants for $\mathrm{Co}$ (II), as reported before. ${ }^{32}$ As the mixing time in the stopped-flow equipment is too short for the metal-loaded species to re-equilibrate upon dilution of the protein sample with substrate, the initial concentrations of the species in the reaction were estimated as one-half the concentration of the corresponding species in the syringe. In the fitting process the rate constants corresponding to binding of $\mathrm{Co}$ (II) were fixed to the values found previously: $k_{\mathrm{on} 1}=$ $0.28 \mu \mathrm{M}^{-1} \cdot \mathrm{s}^{-1}$ and $k_{\mathrm{on} 2}=0.03 \mu \mathrm{M}^{-1} \cdot \mathrm{s}^{-1},{ }^{35}$ and the values of $k_{\text {off }}$ were calculated based on the metal dissociation constants $\left(K_{\mathrm{D} 1}=0.10 \mu \mathrm{M}\right.$, $\left.K_{\mathrm{D} 2}=0.17 \mu \mathrm{M}\right)$ determined by us. ${ }^{32}$ The calculated $k_{\text {off }}$ values were $k_{\text {off } 1}$ $=0.028 \mathrm{~s}^{-1}$ and $k_{\text {off2 }}=0.005 \mathrm{~s}^{-1}$. 


\section{Rapid Freeze-Quench EPR Spectroscopy}

Samples for RFQ-EPR studies were generated using a modified and calibrated Update Instruments (Madison, WI) RFQ system; ${ }^{25}$ reactions were carried out at $2^{\circ} \mathrm{C}$. Concentrations of $\mathrm{Co}$ (II)substituted BcII and imipenem after mixing were $0.5-0.6$ and $5 \mathrm{mM}$, respectively. Hydrolyzed imipenem was prepared by incubation of a solution of $10 \mathrm{mM}$ imipenem in $100 \mathrm{mM}$ Hepes $\mathrm{pH} 7.5,0.2 \mathrm{M} \mathrm{NaCl}$ with $0.15 \mu \mathrm{M}$ holo BcII. Substrate depletion was monitored following absorbance at $300 \mathrm{~nm}$ until completion of the reaction. EPR spectroscopy was performed at either $12 \mathrm{~K}, 1 \mathrm{~mW}$ and $9.63 \mathrm{GHz}$ ( $\boldsymbol{B}_{\text {microwave }} \perp \mathbf{B}_{\text {static }}$ ) or $10 \mathrm{~K}, 50 \mathrm{~mW}$ and $9.37 \mathrm{GHz}$ ( $\boldsymbol{B}_{\text {microwave }} \| \mathbf{B}_{\text {static }}$ ) using a Bruker EleXsys E580 spectrometer equipped with an ER 4116 DM TE $\mathrm{TE}_{012} / \mathrm{TE}_{102}$ dual-mode X-band cavity and an Oxford Instruments ESR-900 helium flow cryostat.

\section{Rapid Freeze-Quench Resonance Raman (RR) Spectroscopy}

Rapid freeze-quench experiments at ca. $30 \mathrm{~ms}$ were performed as described above with a System 1000 apparatus from Update Instruments by mixing equal volumes of $2 \mathrm{mM}$ di-Co(II) BcII and 10 $\mathrm{mM}$ imipenem, both in buffer $100 \mathrm{mM}$ Hepes, $\mathrm{pH} 7.5,200 \mathrm{mM} \mathrm{NaCl}$. After mixing, quenching, and packing, the tube was transferred to a precooled vacuum cryostate $(T=123 \mathrm{~K}$ ) equipped with optical

windows. RR spectra were acquired in backscattering geometry using a Raman microscope (Jobin Yvon, Labram 800-HR) equipped with a long working distance macrosampling lens. The $413 \mathrm{~nm}$ line of a krypton ion laser (Coherent Innova 302) was used for excitation with a power of $15 \mathrm{~mW}$ at sample. Due to the weak signals, spectra were acquired at relatively low resolutions (ca. $1.9 \mathrm{~cm}^{-1}$ per data point) and long accumulation times (typically $5 \mathrm{~min}$ ) over a broad spectral range $\left(300-3500 \mathrm{~cm}^{-1}\right)$. 


\section{Extraction of Hydrolyzed Imipenem and Treatment with Base}

A solution of $2 \mathrm{mM}$ imipenem was subjected to hydrolysis with holo BcII $(3 \mu \mathrm{M})$ in $100 \mathrm{mM} \mathrm{KPi}, 200 \mathrm{mM} \mathrm{NaCl}, \mathrm{pH} 7.5$ at $30{ }^{\circ} \mathrm{C}$. Hydrolyzed imipenem $(1.0 \mathrm{~mL}, 2 \mu \mathrm{mol})$ was extracted with dichloromethane $(8 \times 40 \mathrm{~mL})$, and the collected organic phases were dried with $\mathrm{MgSO}_{4}$. Solvent was evaporated under reduced pressure, and the obtained residue $(6.1 \mathrm{mg})$ was dissolved in tetrahydrofuran (THF). The solution was centrifuged (14.000 rpm, $10 \mathrm{~min})$, and the supernatant was collected. Solvent was evaporated under reduced pressure, and the residue was dried under high vacuum. Hydrolyzed imipenem was dissolved in dry THF (1.2 mL) and transferred via syringe to a spectroscopic cell (with a path length of $1 \mathrm{~cm}$ ), which had been previously dried under high vacuum, capped with a rubber septum, and purged with dry nitrogen. A UV-vis spectrum of the sample was recorded $(280-800 \mathrm{~nm})$ in a JASCO V-550 spectrophotometer.

A $12 \mathrm{mM}$ sodium hexamethyldisilazide (NaHMDS) solution was prepared by diluting a $0.6 \mathrm{~N}$ NaHMDS toluene solution $(100 \mu \mathrm{L})$ in anhydrous THF $(5.0 \mathrm{~mL})$. At room temperature, two additions of the NaHMDS dilution were done $(100 \mu \mathrm{L}, 1.2 \mu \mathrm{mol})$ to the hydrolyzed imipenem and the UV-vis spectra were recorded. The effect of the base was reverted by addition of glacial acetic acid $(5 \mu \mathrm{L}, 87.5 \mu \mathrm{mol})$. The corresponding controls were done with a solution of toluene (100 $\mu \mathrm{L})$ in THF (5.0 mL) and NaHMDS in identical conditions of the assay. The same analysis was done using triethylamine (TEA) as base (100 $\mu \mathrm{L}, 720 \mu \mathrm{mol})$.

\section{Computational Methods}

All calculations were performed using the Gaussian-03 program, ${ }^{36}$ with the B3LyP Correlation Exchange Functional and a 6$31 \mathrm{G} * *$ basis set for atoms $\mathrm{C}, \mathrm{N}, \mathrm{H}, \mathrm{O}$ and a LanL2DZ basis for the Co atom. Prior to the frequency calculations all structures were optimized at the same level of theory. The electronic spectra were computed using TD-DFT at the same level of theory. Starting structures for the cobalt-coordinated intermediate complex were built based on the 
NOT THE PUBLISHED VERSION; this is the author's final, peer-reviewed manuscript. The published version may be accessed by following the link in the citation at the bottom of the page.

proteins active site structure for the $\mathrm{Zn}$ carbapenemase CphA in complex with biapenem ( $p d b$ code $1 \times 8 \mathrm{i}$ ).

\section{Results}

\section{Stopped-Flow/Photodiode Array Experiments}

Upon addition of 2 equiv of $\mathrm{Co}(\mathrm{II})$ to apo BcII, the resultant species di-Co(II) BcII exhibited a LMCT band at $343 \mathrm{~nm}$ that corresponds to the Cys-Co(II) bond from the DCH site, while a characteristic band pattern is observed in the $480-650 \mathrm{~nm}$ region from ligand field transitions distinctive of the $3 \mathrm{H}$ site. ${ }^{18,32,35}$ Spectra recorded during the reaction of $83 \mu \mathrm{M}$ di-Co(II) BcII with $2.5 \mathrm{mM}$ imipenem at $6{ }^{\circ} \mathrm{C}$ (Figure 1 ) showed accumulation of a catalytically active species with a strong absorption band at $407 \mathrm{~nm}$ that dominated the spectrum in the visible range. Analysis of the differential spectra revealed that the ligand field bands in the visible region were modified during the reaction, compared to the restingstate enzyme, and recovered their distinctive features when the reaction was over.
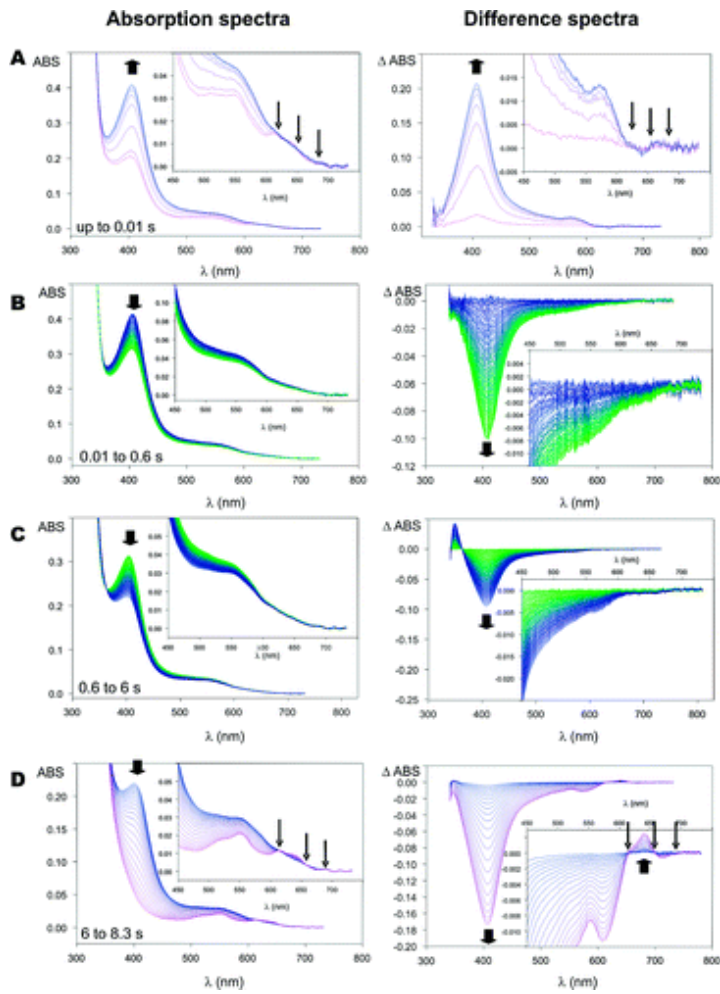

Journal of the American Chemical Society, Vol 130, No. 47 (November 26, 2008): pg. 15852-15863. DOI. This article is (C) American Chemical Society and permission has been granted for this version to appear in e-Publications@Marquette. American Chemical Society does not grant permission for this article to be further copied/distributed or hosted elsewhere without the express permission from American Chemical Society. 
Figure 1. Electronic absorption spectra of di-Co(II) BcII during imipenem hydrolysis $([\mathrm{BCII}]=83 \mu \mathrm{M} ;[\mathrm{Co}(\mathrm{II})]=166 \mu \mathrm{M}$; [imipenem $]=2500 \mu \mathrm{M})$. The reaction was carried out at $6^{\circ} \mathrm{C}$ in a stopped-flow system associated with a photodiode-array detector. The spectra were recorded on a logarithmic base with an integration time of $1.28 \mathrm{~ms}$. Graphics on the left show the evolution of the absolute spectra while graphics on the right correspond to the difference spectra obtained by subtraction of the first spectrum of the time interval shown. Thick arrows indicate progress of the bands; thin arrows point to isosbestic points. Insets show a magnification of the $450-750 \mathrm{~nm}$ region.

Analysis of the progression of the spectra allowed us to distinguish four discrete steps. During the first one (up to $10 \mathrm{~ms}$, Figure $1 \mathrm{~A}$ ) the spectrum of resting-state di-Co(II) BcII disappeared, giving rise to a new species, $\mathrm{EI}^{1}$. $\mathrm{EI}^{1}$ displayed an intense band with a maximum at $407 \mathrm{~nm}$ and a broad feature in the $\mathrm{d}-\mathrm{d}$ band region with a maximum at around $575 \mathrm{~nm}$. The $\mathrm{E} \rightarrow \mathrm{EI}^{1}$ transition was characterized by isosbestic points at 615, 660, and $685 \mathrm{~nm}$. Then, EI ${ }^{1}$ decayed rapidly in a second phase from 10 to $600 \mathrm{~ms}$ without showing any isosbestic point (Figure 1B). This was consistent with conversion of $\mathrm{EI}^{1}$ into a spectroscopically silent species or into a species with similar spectral features but lower absorptivity $\left(\mathrm{EI}^{2}\right)$. Then, a third species built up as $\mathrm{EI}^{1}$ continued to decay at a slower rate $(0.6-6.0 \mathrm{~s}$, Figure $1 \mathrm{C})$. This third adduct $\left(\mathrm{EI}^{3}\right)$ and $\mathrm{EI}^{1}$ seemed to display similar $\mathrm{d}-\mathrm{d}$ features ( $E \mathrm{I}^{1}$ showing a higher extinction coefficient though). $E \mathrm{I}^{1}$ then decayed into $E(6.0-8.3 \mathrm{~s})$ after substrate depletion with isosbestic points at 615,660, and $685 \mathrm{~nm}$ (Figure 1D).

When the reaction was run employing different $\mathrm{Co}$ (II)/BcII ratios, ranging from 0.3 to 2 , the spectra of the intermediate species involved were identical and the same sequence of steps was observed. This suggested that the main catalytic pathway and the active species involved were the same or at least showed very similar spectroscopic features irrespective of the amount of metal loaded onto the enzyme. This behavior resembled the one observed for penicillin hydrolysis by Co(II)-BcII.

The changes observed in the visible range of the spectrum during the reaction revealed changes in the geometry of the $\mathrm{Co}$ (II) ion bound to the $3 \mathrm{H}$ site upon catalysis, as disclosed by the disappearance of the characteristic four-band pattern associated with this site. Events occurring at the DCH site were unclear in these experiments since the spectral region where the LMCT band is located (343 nm) was 
obscured by the intense absorption of the substrate and product during the reaction. We initially attributed the intense feature at 407 $\mathrm{nm}$ to a Cys $\rightarrow \mathrm{Co}$ (II) LMCT band during turnover. In an attempt to observe the enzyme's features in the UV region during catalysis, we carried out the same reaction at a lower substrate concentration (100 $\mu \mathrm{M}$ imipenem). Under these conditions, the sequence of spectra was identical to the one described above (Figure S9, Supporting Information). Even though it was still difficult to follow due to substrate interference, we could distinguish that the absorption at 343 $\mathrm{nm}$ corresponding to the resting enzyme was not decreasing noticeably while the $407 \mathrm{~nm}$ band intensity showed its maximal rise. This suggested that the $407 \mathrm{~nm}$ feature did not correspond to the enzyme's CT band undergoing a red shift upon turnover. This observation led us to question the assignment of the $407 \mathrm{~nm}$ feature to a Cys $\rightarrow \mathrm{Co}$ (II) LMCT band.

\section{Kinetic Analysis and Proposed Mechanism}

In order to derive a minimal kinetic mechanism from the UV-vis data we fitted the single-wavelength absorption traces to different basic reaction schemes. We performed the reaction of BcII substituted with different amounts of Co(II) versus various concentrations of imipenem. The data were subjected to simultaneous global fit using the software Dynafit (Biokin). ${ }^{34}$

At this point we must recall that at substoichoimetric Co(II)/BcII ratios the protein exists as a mixture of apo-, mono-, and di-Co(II) BcII. ${ }^{32}$ Moreover, mono-Co(II) BcII consists of two species in equilibrium, i.e., those with the metal ion localized at the $3 \mathrm{H}$ and $\mathrm{DCH}$ site. $^{32,35}$ The equilibria between the differently metallated forms were considered in all models tested.

The study of the time evolution of the absorbance traces made it necessary to include a branching point in the hydrolysis pathway, resembling the behavior exhibited by $\mathrm{Co}(\mathrm{II})-\mathrm{BcII}$ toward penicillin $\mathrm{G}$ (see Figures S1 and S2 in the Supporting Information and the accompanying paper). ${ }^{37}$ When we analyzed the fits obtained when assuming that only the dinuclear species was active during the reaction (Figures S3 and S4, Supporting Information) it was evident 
that a further increase in the complexity of the model was required. The predicted reaction rates were much slower than those actually observed at low Co(II) concentrations. This difference could be worked out by considering that the mononuclear species in equilibrium with apo and dinuclear BcII had significant catalytic activity (Figure 2).

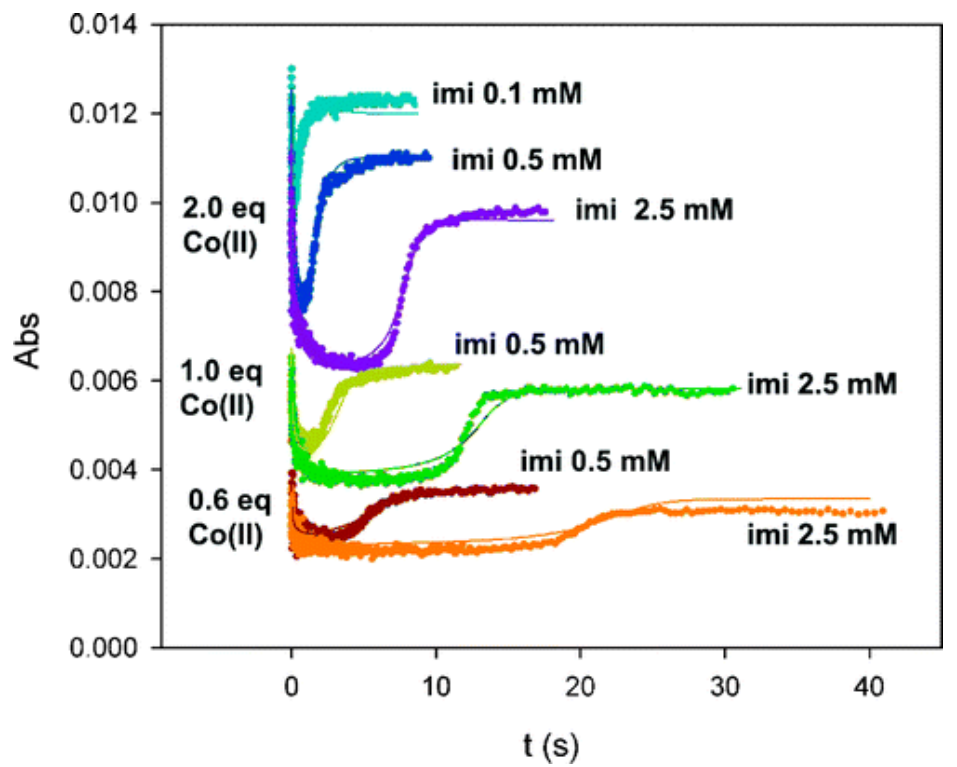

Figure 2. Global fit of traces at $640 \mathrm{~nm}$ to the kinetic model shown in Scheme 1 during imipenem hydrolysis with BcII $(83 \mu \mathrm{M})$ loaded with different amounts of $\mathrm{Co}(\mathrm{II})$. Experimental data are represented with dots, and fits are shown overlaid as continuous traces. The concentration of imipenem and number of $\mathrm{Co}$ (II) equivalents added to the protein sample in each case are indicated on the graph.

Analysis of each and every one of these issues lead to the model shown in Scheme 1 for imipenem hydrolysis. This mechanism accounts for all of the species and steps revealed during the stopped-flow experiments and gives a satisfactory global fit of the traces corresponding to three different $\mathrm{Co}$ (II)/BcII ratios $(0.6,1.0$, and 2.0 Co(II) equivalents) and three imipenem concentrations $(0.1,0.5$, and $2.5 \mathrm{mM}$ ) (Figures 2 and S5 (Supporting Information)). In every case the initial concentrations of apo $(A)$, mononuclear $(M)$, and dinuclear (E) enzyme were calculated using the macroscopic dissociation constants previously reported. ${ }^{32}$ The data were processed altogether and successfully fitted to the proposed mechanism using nonlinear least-squares regression (Dynafit, Biokin). We decided to fit the traces at $640 \mathrm{~nm}$ since measurements at this wavelength allow following the accumulation of intermediates during turnover as well as recovery of the resting enzyme after substrate depletion. The experimental traces 
at $640 \mathrm{~nm}$ and fitted curves are shown overlaid in Figure 2. Individual rate constants estimated from the fit are shown in Table 1 . In the fit the extinction coefficients of the different species were allowed to vary, giving final values in accordance with the previous examination of the spectra (Table 1). Given the characteristics of the transitions, some of which do not exhibit noticeable changes in absorbance at $640 \mathrm{~nm}$, a few of the rate constants could not be determined. These parameters appear as ND (not determined) in Table 1 . The case of $k_{+6}$ and $k_{-6}$ deserves a special comment since even when these parameters could not be estimated individually the ratio between them was always 700 $\mu \mathrm{M}$, reflecting the value of $K_{\mathrm{D}}$ for the $\mathrm{EI}^{3} / \mathrm{EP}$ adduct.

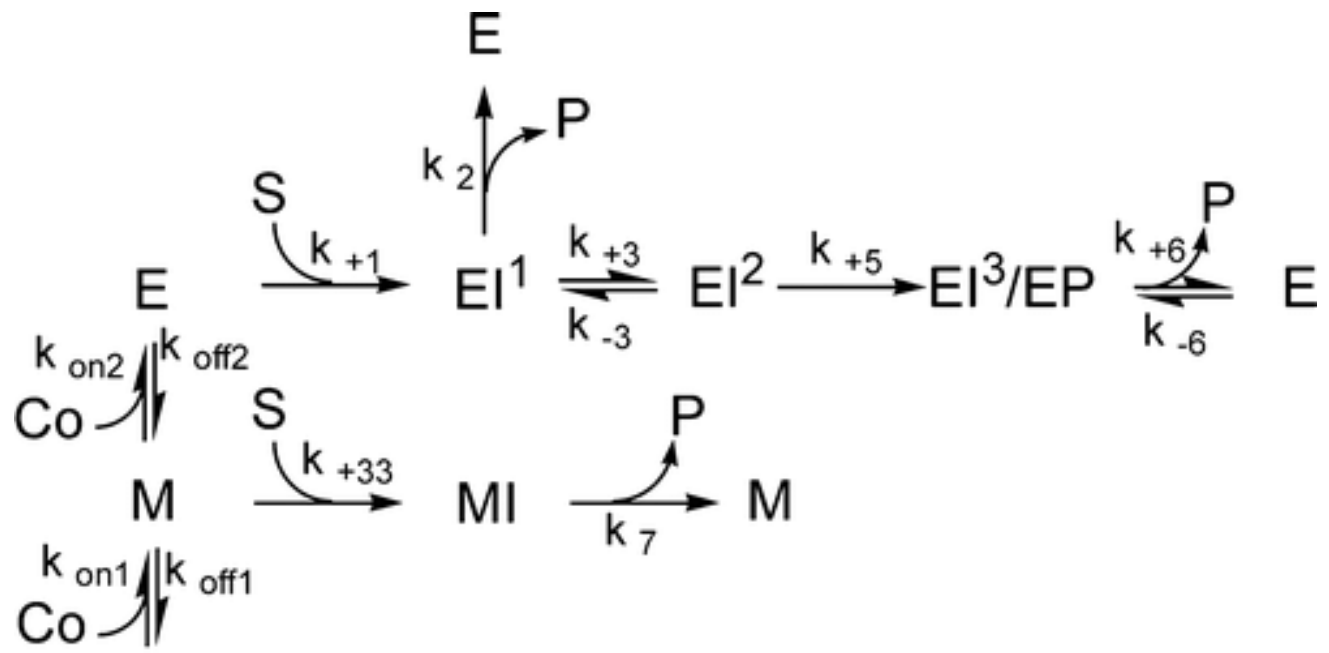

Scheme 1. Proposed Kinetic Mechanism

Table 1. Parameters Obtained from the Fit to the Kinetic Model Shown in Scheme 1 of the Changes of the Intensity of Absorption at $640 \mathrm{~nm}$ during the Reaction of Co(II)-Substituted BcII with Imipenem ${ }^{a}$

$\begin{array}{lll}k_{+1}\left(\mu \mathrm{M}^{-1} \cdot \mathrm{s}^{-1}\right) & 0.22088 & 3.6 \\ k_{2}\left(\mathrm{~s}^{-1}\right) & 6.3318 & 3.3 \\ k_{+3}\left(\mathrm{~s}^{-1}\right) & 0.60159 & 3.4 \\ k_{-3}\left(\mathrm{~s}^{-1}\right)^{\mathrm{b}} & \mathrm{ND}^{\mathrm{b}} & \mathrm{ND}^{\mathrm{b}} \\ k_{5}\left(\mathrm{~s}^{-1}\right) & 0.95 & 71 \\ k_{+6} / k_{-6}(\mu \mathrm{M})^{\mathrm{c}} & \sim 700^{\mathrm{c}} & \mathrm{ND}^{\mathrm{c}} \\ k_{+33}\left(\mu \mathrm{M}^{-1} \cdot \mathrm{s}^{-1}\right) & 0.016498 & 8 \\ k_{7}\left(\mathrm{~s}^{-1}\right) & 3.501 & 3.7 \\ r_{\mathrm{E}}\left(\mathrm{M}^{-1} \cdot \mathrm{cm}^{-1}\right) & 167.766 & 0.3\end{array}$

Journal of the American Chemical Society, Vol 130, No. 47 (November 26, 2008): pg. 15852-15863. DOI. This article is (C) American Chemical Society and permission has been granted for this version to appear in e-Publications@Marquette. American Chemical Society does not grant permission for this article to be further copied/distributed or hosted elsewhere without the express permission from American Chemical Society. 
NOT THE PUBLISHED VERSION; this is the author's final, peer-reviewed manuscript. The published version may be accessed by following the link in the citation at the bottom of the page.

parameter

$r_{\mathrm{EI}}^{1}\left(\mathrm{M}^{-1} \cdot \mathrm{cm}^{-1}\right)$

$r_{\mathrm{EP}}\left(\mathrm{M}^{-1} \cdot \mathrm{cm}^{-1}\right)$

$r_{\mathrm{M}}\left(\mathrm{M}^{-1} \cdot \mathrm{cm}^{-1}\right)$

$r_{\mathrm{MI}}\left(\mathrm{M}^{-1} \cdot \mathrm{cm}^{-1}\right)$

$k_{\mathrm{on} 1}\left(\mu \mathrm{M}^{-1} \cdot \mathrm{s}^{-1}\right)$

$k_{\mathrm{off} 1}\left(\mathrm{~s}^{-1}\right)$

$k_{\mathrm{on} 2}\left(\mu \mathrm{M}^{-1} \cdot \mathrm{s}^{-1}\right)$

$k_{\text {off2 }}\left(\mathrm{s}^{-1}\right)$ fitted values

116.057

111.44

84.3

58.1

0.28

0.028

0.03

0.005
$\%$ error

0.4

1

0.7

1.1

fixed $^{\text {d }}$

fixed $^{d}$

fixed $^{\mathrm{d}}$

fixed $^{\mathrm{d}}$

aThe response $(r)$ corresponds to the extinction coefficient of each species.

bThis constant could not be estimated from these experiments.

'The individual values of $k_{+6}$ and $k_{-6}$ were not constrained by this set of data, but in all the events of fitting the ratio $k_{+6} / k_{-6}$ was constant and equal to $700 \mu \mathrm{M}$.

dThe rate constants corresponding to binding of $\mathrm{Co}$ (II) to BcII were fixed to the values by Seny et al. The values of $k_{\text {off }}$ were calculated based on the metal dissociation constants determined previously $\left(K_{\mathrm{D} 1}=0.1 \mu \mathrm{M}\right.$ and $K_{\mathrm{D} 2}=0.17 \mu \mathrm{M}$, see ref 32$)$.

Figure 2 reveals that recovery of the resting enzyme's features was compromised at higher substrate concentrations, suggesting the possible formation of a stable enzyme-product (EP) adduct. This was confirmed by adding hydrolyzed imipenem (P) to di-Co(II) BcII, which gave rise to a perturbed UV-vis spectrum (Figure S6, Supporting Information). Subtraction of the spectrum of resting $\mathrm{Co}$ (II)-BcII revealed the spectroscopic features of the EP complex, whose absorptivity at $640 \mathrm{~nm}$ was significantly reduced compared to the free enzyme. The calculated absorptivity of $\mathrm{EI}^{3}$ (Table 1 ) was consistent with this spectrum, allowing us to designate this species as EP in the kinetic model.

The time evolution of the intense $407 \mathrm{~nm}$ band was independently fitted to the same models including different Co(II)/BcII ratios and different imipenem concentrations (Figure S5, Supporting Information). As shown in Table 1 and Figures 2 and S1-S5 (Supporting Information), the model shown in Scheme 1 was the best minimal model that allowed us to account for the time evolution at both 407 and $640 \mathrm{~nm}$.

The proposed model for imipenem hydrolysis is in agreement with that derived from independent experiments run with penicillin $\mathrm{G}$ (see accompanying paper) in that a monometallated form of the enzyme has a significant catalytic activity and both the mononuclear 
and dinuclear intermediates have similar features in the electronic spectra. There are, however, two major features of imipenem hydrolysis that are unique: formation of a stable enzyme-product adduct $\left(\mathrm{EI}^{3} / \mathrm{EP}\right)$ and the fact that both branches of the pathway for the dinuclear species are productive.

\section{Rapid Freeze-Quench EPR}

EPR spectra of BcII containing 0.5 equiv of $\mathrm{Co}$ (II) (' $\mathrm{CO}_{0.5}-\mathrm{BcII}^{\prime}$ ) after reaction with imipenem are shown in Figure 3. A marked change in the appearance of the spectrum was observed upon incubation of $\mathrm{CO}_{0.5}$-BcII with imipenem for $10 \mathrm{~ms}$ (Figure 3B), indicating formation of a new species within the same time scale monitored in the stoppedflow experiments. The new species persisted at $200 \mathrm{~ms}$ (Figure 3C). Upon exhaustion of substrate, the EPR spectrum resembled that from the resting signal, though slight differences could be seen, particularly in the range 3000-4000 G (300-400 mT). Upon direct addition of the hydrolysis product of imipenem to $\mathrm{Co}_{0.5}-\mathrm{BcII}$ (Figure $3 \mathrm{~F}$ ), the signal was again similar, but not identical, to the resting signal.

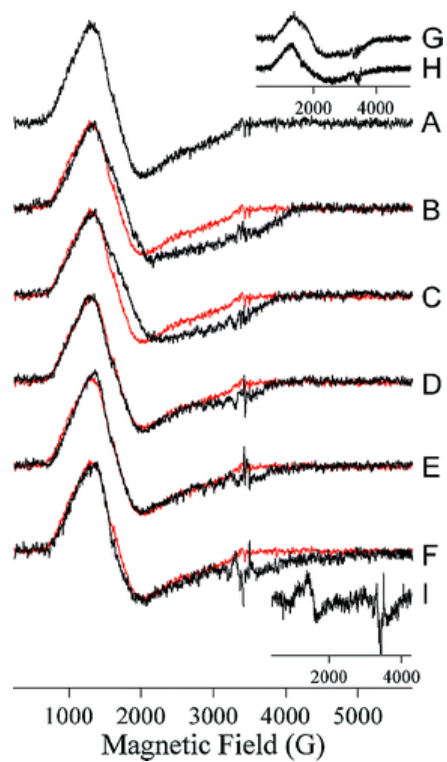

Figure 3. Perpendicular mode EPR spectra of 0.5 equiv of $\mathrm{Co}(\mathrm{II})$-substituted BcII $\left(\mathrm{CO}_{0.5}-\mathrm{BCII}\right)$ upon reaction with imipenem. The traces shown in black in $\mathrm{A}-\mathrm{F}$ correspond to resting $\mathrm{BcII}$ to which 0.5 equiv of $\mathrm{Co}$ (II) was added (A); $\mathrm{Co}_{0.5}-\mathrm{BcII}$ incubated with imipenem for $10 \mathrm{~ms}$ (B), $200 \mathrm{~ms}(C), 12 \mathrm{~s}(\mathrm{D})$, and $1 \mathrm{~h}(\mathrm{E})$. Trace $\mathrm{F}$ (black) is the spectrum of $\mathrm{CO}_{0.5}-\mathrm{BcII}$ incubated with the BcII hydrolysis product of imipenem. The red traces underlying the black traces in traces $B-F$ are of resting $\mathrm{Co}_{0.5}-\mathrm{BcII}$, as in trace A. The insets show difference spectra calculated from A-F 
along with resting species for comparison. Trace $\mathrm{G}=\mathrm{C}-(0.43 \times \mathrm{A})$. Trace $\mathrm{H}$ is an axial signal exhibited by BcII during titration with $\mathrm{Co}$ (II) [Figure $3 \mathrm{C}$ (C) of ref 32 . Trace $\mathrm{I}=\mathrm{F}-(0.8 \times \mathrm{A})$. Experimental spectra $\mathrm{A}-\mathrm{F}$ were recorded at $9.63 \mathrm{GHz}, 12 \mathrm{~K}, 1 \mathrm{~mW}$ microwave power, and $12 \mathrm{G}(1.2 \mathrm{mT})$ magnetic field modulation at $100 \mathrm{kHz}$.

At $10 \mathrm{~ms}$ reaction time the change in the spectrum from the resting state was due to at least two phenomena. First, a new, broad species (Figure 3G) was observed that was only slightly rhombic (there is a shoulder at $1900 \mathrm{G}$ [190 mT]) and is otherwise similar to an axial species observed during titration of BcII with Co(II). ${ }^{32}$ Second, a barely discernible feature to the low-field side of the major absorption feature (500-600 G [50-60 mT]) was suggestive of an integral spin system. After extended reaction time or addition of hydrolysis product, the spectrum differs from that of resting enzyme by the presence of a small amount of an additional axial signal (Figure 3I).

Upon reaction of di-Co(II) BcII with imipenem the most striking change in the spectrum was the very clear appearance of a low-field feature (600-700 G; 60-70 mT), suggestive of an integer-spin system (Figure 4B). Additional broad featureless absorption from 2500 to $5500 \mathrm{G} \mathrm{(250} \mathrm{to} 550 \mathrm{mT}$ ) was observed (Figure 4B), though this could not be associated with a well-defined signal, in contrast to the case with $\mathrm{CO}_{0.5}-\mathrm{BcII}$. Neither of these features persisted beyond the pre-steady-state regime, characteristic of reaction intermediates (Figure 4C). In addition, minor changes in the spectrum were observed that may or may not have catalytic relevance. Upon reaction of di$\mathrm{Co}$ (II) BcII an axial signal (Figure 4E) was isolated by difference and is observable in the raw experimental spectrum as a step at $1000 \mathrm{G}$ (100 $\mathrm{mT}$ ). Reverse subtraction, i.e. Figure $4 \mathrm{~A}$ and $4 \mathrm{~B}$, suggested loss of an EPR signal hitherto exhibited by resting di-Co(II) BcII; a rhombic component (Figure 4F) of the resting signal (Figure 4A), similar to that isolated as a component of the resting signal during titration of BcII with $\mathrm{Co}(\mathrm{II})$ (Figure 4G), ${ }^{32}$ was diminished upon reaction with imipenem. This phenomenon was not observed in the reaction of $\mathrm{Co}_{0.5}$ - BcII with imipenem because the rhombic component's contribution to the resting spectrum of $\mathrm{CO}_{0.5}-\mathrm{BcII}$ is very low. ${ }^{32}$ 


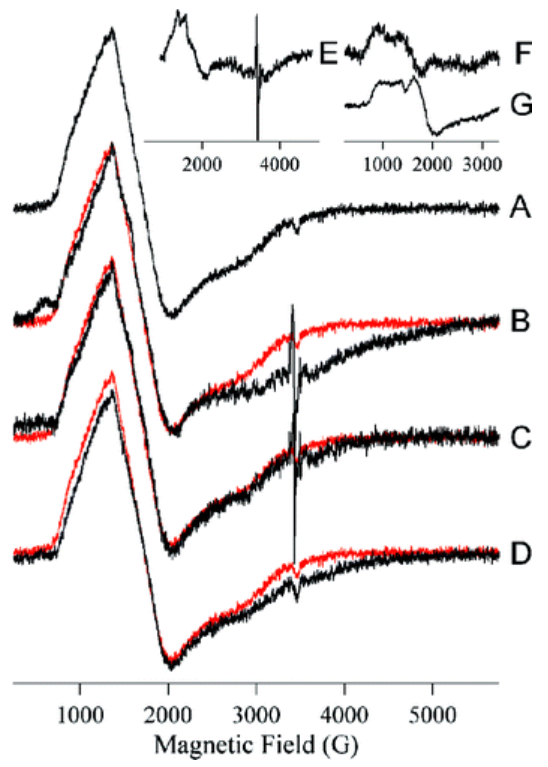

Figure 4. Perpendicular mode EPR spectra of 2.0 equiv of Co(II)-substituted BcII (di$\mathrm{Co}$ (II) BcII) upon reaction with imipenem. The traces shown in black in $\mathrm{A}-\mathrm{C}$ correspond to resting BcII to which 2.0 equiv of $\mathrm{Co}$ (II) was added (A); di-Co(II) BcII incubated with imipenem for 10 (B) and $200 \mathrm{~ms}$ (C). Trace $D$ (black) is the spectrum of di-Co(II) BcII incubated with the BcII hydrolysis product of imipenem. The red traces underlying the black traces in Traces B-D are of resting di-Co(II) BcII, as in trace $A$. The insets show difference spectra calculated from $A-D$ along with resting species for comparison. Trace $E=B-(0.65 \times A)$. Trace $F=A-(0.9 \times B)$. Trace $G$ is a rhombic signal exhibited by BcII during titration with $\mathrm{Co}$ (II) [Figure $3 \mathrm{C}(\mathrm{B})$ of ref 32]. Experimental spectra A-D were recorded at $9.63 \mathrm{GHz}, 12 \mathrm{~K}, 1 \mathrm{~mW}$ microwave power, and $12 \mathrm{G}(1.2 \mathrm{mT})$ magnetic field modulation at $100 \mathrm{kHz}$.

With both $\mathrm{CO}_{0.5}-\mathrm{BCII}$ and di-Co(II) BcII reaction with imipenem elicited clear changes in the $S=3 / 2 \mathrm{Co}$ (II) signals that are due to a reversible change in the environment of a significant proportion of the magnetically isolated $\mathrm{Co}$ (II) component. These changes occur in the time frame of the enzymatic reaction and differ between $\mathrm{Co}_{0.5}-\mathrm{BcII}$ and di-Co(II) BcII. Little structural information is forthcoming, however, due to the poorly resolved nature of the new species. In addition, there is evidence for the appearance and disappearance of an integer spin system in di-Co(II) BcII upon reaction with imipenem.

Parallel mode EPR was used to further investigate the suggestion of the development of an integer-spin system during the reaction (Figure 5). A weak parallel mode signal was exhibited by both resting $\mathrm{Co}_{0.5}-\mathrm{BcII}$ and di-Co(II) BcII, although the signal from $\mathrm{Co}_{0.5}$-BcII was about 5-fold less intense than that from di-Co(II) BcII. The envelopes of the spectra were completely within the magnetic field scale, indicating that the zero-field splitting (ZFS) due to spin-spin 
coupling is small and its entire distribution lies below the microwave quantum energy. Upon reaction with imipenem for $10 \mathrm{~ms}$, the parallel mode signals from both $\mathrm{CO}_{0.5}-\mathrm{BcII}$ and di-Co(II) BcII more than doubled in intensity and, importantly, shifted $60 \mathrm{G}(6 \mathrm{mT})$ to lower field, indicating a small imipenem-dependent change in the mean ZFS with kinetics compatible with enzyme catalysis (Figure 5B). In the early steady state the spectrum was indistinguishable from that after $10 \mathrm{~ms}$ except that the intensity was diminished (Figure 5C). Upon exhaustion of substrate, the signal was shifted a further $50 \mathrm{G}$ (5 mT) downfield. Addition of hydrolyzed imipenem to the enzyme gave rise to the spectra shown in Figure 5D, confirming that the product binds the active site.

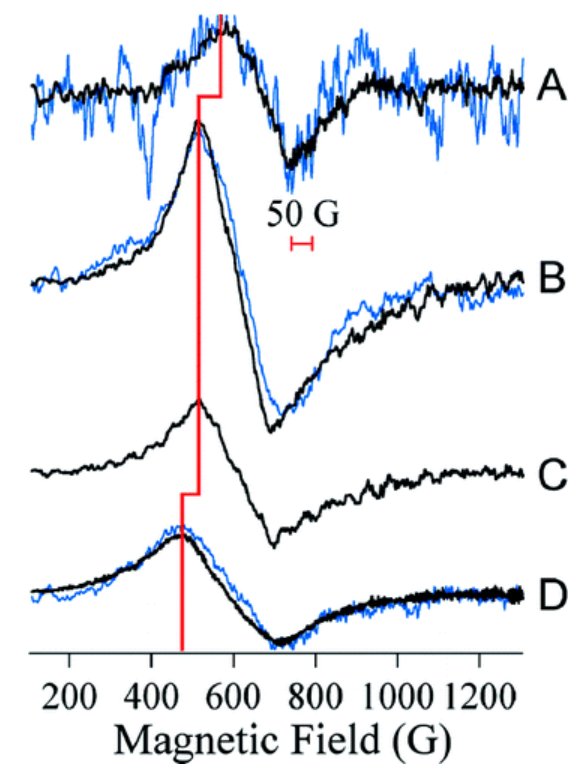

Figure 5. Parallel mode EPR spectra of $\mathrm{Co}$ (II)-substituted BcII upon reaction with imipenem. The black spectra A-D were exhibited by di-Co(II) BcII and correspond to resting di-Co(II) BcII (A); di-Co(II) BcII incubated with imipenem for 10 (B) and 200 $\mathrm{ms}(\mathrm{C})$. Trace $\mathrm{D}$ (black) is the spectrum of di-Co(II) BcII incubated with the BcII hydrolysis product of imipenem. The blue traces of $A, B$, and $D$ are the analogous spectra (resting, $10 \mathrm{~ms}$ with imipenem, and product treated) for $\mathrm{Co}_{0.5}-\mathrm{BcII}$. The intensities of the blue traces are each shown multiplied by a factor of 5 relative to the black traces. The red line shows the field positions of the maxima of the signals, and the red bar corresponds to a field span of $50 \mathrm{G}(5 \mathrm{mT})$. Spectra were recorded at 9.38 $\mathrm{GHz}, 10 \mathrm{~K}, 50 \mathrm{~mW}$ microwave power, and $12 \mathrm{G}(1.2 \mathrm{mT})$ magnetic field modulation at $100 \mathrm{kHz}$.

Using the mechanism described in the previous section and the set of constants obtained with the stopped flow data we simulated the different species accumulating under the conditions of the RFQ reactions (Figure S7, Supporting Information) and found that the 
major intermediates predicted to accumulate in the reaction with 0.5 $\mathrm{Co}(\mathrm{II}) / \mathrm{BcII}$ and $2.0 \mathrm{Co}$ (II)/BcII are different, namely, MI and $\mathrm{EI}^{1}$, respectively. Given that the resting distributions of $\mathrm{Co}$ (II) in $\mathrm{CO}_{0.5}-\mathrm{BcII}$ and di-Co(II) BcII differ, ${ }^{32}$ this is hardly surprising. The potential for formation of a spin-coupled dinuclear site is clearly higher in di-Co(II) BcII, and the rhombic species of magnetically isolated $\mathrm{Co}$ (II) observed in di-Co(II) BcII is barely present in $\mathrm{CO}_{0.5}-\mathrm{BcII}$. Thus, in the EPR of $\mathrm{Co}_{0.5}-\mathrm{BcII}$ the large change in the $S=3 / 2 \mathrm{Co}$ (II) signal observed is attributable to a magnetically isolated ('mononuclear') $\mathrm{Co}$ (II)-centered reaction intermediate. In contrast, with di-Co(II) BcII the changes in the $S=3 / 2$ signals are smaller and less well defined and the major intermediate species is the spin-coupled $(S=0,1,2,3)$ species that gives rise to the integer spin signal.

The observation of new signals in perpendicular mode after 10 ms is well within the turnover time and corresponds to the appearance of the first stopped-flow-detected species, i.e., that with absorbance at $407 \mathrm{~nm}$, both at 0.5 and $2 \mathrm{Co}$ (II) equivalents. These data confirm that the $407 \mathrm{~nm}$ absorption is present in both the mononuclear (MI) and dinuclear intermediates $\left(\mathrm{EI}^{1}\right)$.

\section{Spectroscopic and Chemical Characterization of a Reaction Intermediate}

At this point we were only left with the identification of the intermediate species. In order to assign the intense band at $407 \mathrm{~nm}$, attributed to species $\mathrm{EI}^{1}$, we performed a rapid freeze-quench resonance Raman experiment in which the reaction was allowed to proceed for $30 \mathrm{~ms}$ and then quenched by freezing. The sample was excited with a $413 \mathrm{~nm}$ laser, and the RR spectrum was recorded (Figure 6). Neither the free enzyme nor the free substrate exhibited any clear RR signal in the entire spectral range $\left(300-3500 \mathrm{~cm}^{-1}\right.$ ) under these experimental conditions. This was also true for the mixture of enzyme and substrate prepared at room temperature (consisting mainly of EP and free enzyme). The reaction mixture quenched at $30 \mathrm{~ms}$ showed a clear band at $1541 \mathrm{~cm}^{-1}$ which was the only distinct feature that could be ascribed to the reaction intermediate $\mathrm{EI}^{1}$ (note that all other prominent bands that appear in Figure 6 correspond to isopentane signals). This observation further confirmed 
that the $407 \mathrm{~nm}$ absorption was not due to a Cys $\rightarrow \mathrm{Co}$ (II) chromophore and at the same time (being the only detected band) imposed a severe constrain for a sound vibrational assignment. The frequency of this band was consistent with a normal mode with a high contribution of one or more $\mathrm{C}=\mathrm{C}$ or $\mathrm{C}=\mathrm{N}$ double-bond stretchings. ${ }^{38}$ Hence, the chromophore responsible for the large feature at $407 \mathrm{~nm}$ was an organic moiety arising from the unique chemical nature of the substrate since this feature was not observed in similar experiments in which penicillin $\mathrm{G}$ (see accompanying article) or cefotaxime (not shown) were used as substrates.

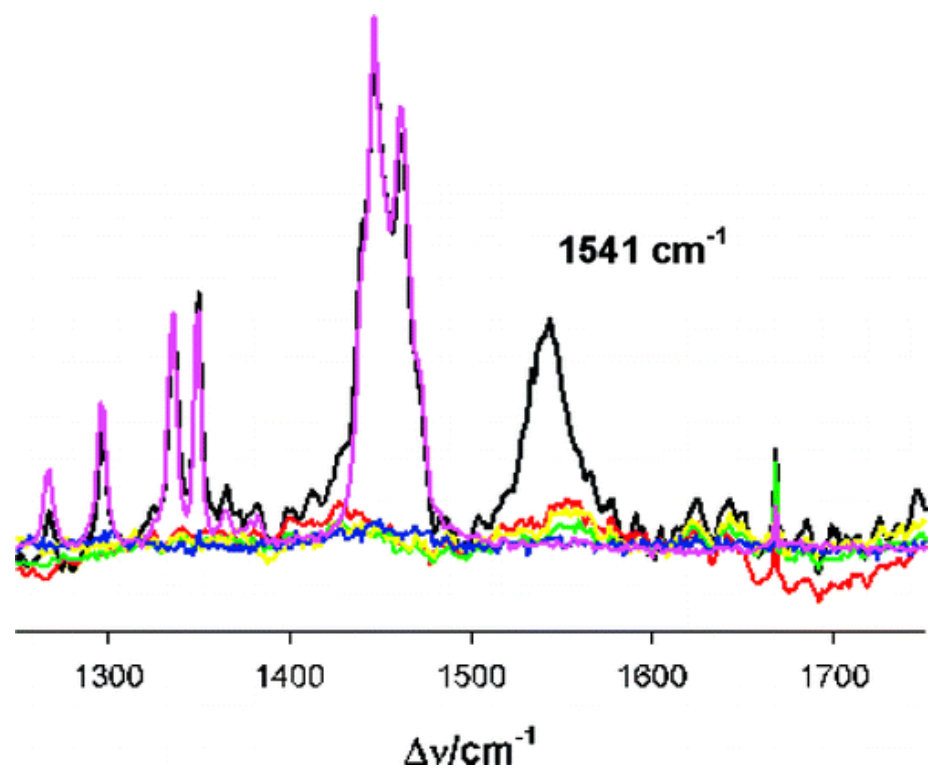

Figure 6. Resonance Raman spectrum of $\mathrm{Co}$ (II)-BcII after $30 \mathrm{~ms}$ of mixing with imipenem (black). The final concentrations in the mix were $1 \mathrm{mM}$ di-Co(II) BcII and 5 mM imipenem in 100 mM Hepes, pH 7.5, 200 mM NaCl. Controls: isopentane mix (pink), imipenem (red), di-Co(II) BcII (yellow), buffer (blue), and di-Co(II) BcII after reaction with imipenem at room temperature (green). Excitation laser: $413 \mathrm{~nm}$.

Carbapenem hydrolysis is usually followed by tautomerization of the double bond in the pyrroline ring from the $\Delta^{2}$ to the $\Delta^{1}$ position (Scheme 2). ${ }^{39}$ This process has been shown to occur in carbapenem hydrolysis by the class A lactamase TEM-1 after formation of an acyl-enzyme covalent adduct ${ }^{40,41}$ as well as in acid-mediated hydrolysis in solution. ${ }^{39}$ We characterized the reaction products resulting from imipenem hydrolysis by $\mathrm{Zn}$ (II)-BcII and $\mathrm{Co}$ (II)-BcII by ${ }^{1} \mathrm{H}$ NMR spectroscopy. ${ }^{39}$ In both cases the detected product was tautomer $\Delta^{1}$, i.e., having experienced double-bond migration. Acidmediated hydrolysis of imipenem gives rise to equal amounts of the 
two possible diasteromers resulting from protonation from either the a or the $\beta$ face. Instead, BcII-mediated hydrolysis resulted in a 7:3 ratio of diasteromers, suggesting some diasteroselectivity in the protonation of the carbanionic species at C-3, which is expected to occur within the enzyme active site.

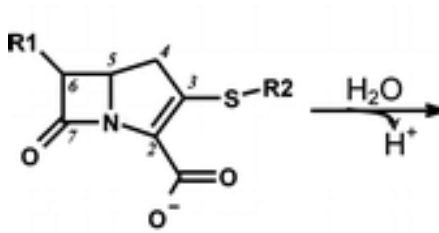

Imipenem<smiles>[R2]SC1=C(C(=O)[O-])N([2H])C(C([R])C(=O)[O-])C1C</smiles>

$\Delta^{2}$ tautomer

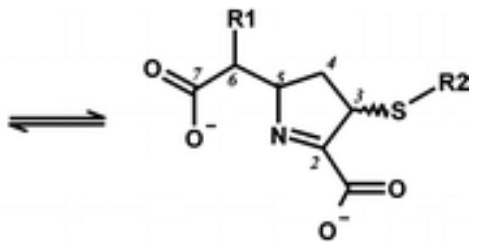

$\Delta^{1}$ tautomer

Scheme 2. Imipenem Tautomerization upon Hydrolysis

The reported $\Delta^{2} \rightarrow \Delta^{1}$ tautomerization is likely to occur via an anionic intermediate. ${ }^{39}$ In an attempt to reproduce this species, hydrolyzed imipenem was treated with a strong base under anhydrous conditions. Figure 7 shows the UV-vis spectrum of hydrolyzed imipenem in tetrahydrofuran (THF) and treated with sodium hexamethyldisilazide (NaHMDS). The resulting species exhibited two intense absorption bands at 330 and $380 \mathrm{~nm}$ (Figure 7, black trace) that were absent in the hydrolysis products. The same spectrum was obtained when triethylamine (TEA) was used as the organic base. In both cases, these bands disappeared upon treatment with acetic acid.

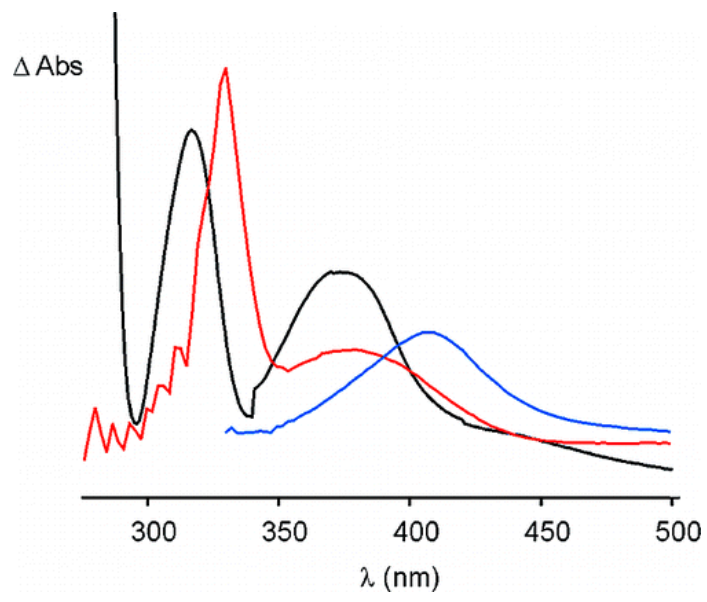

Figure 7. Electronic absorption spectra of hydrolyzed imipenem in THF with NaHMDS (black line). Also shown for comparison are the spectra of the intermediates that accumulate during reaction of holo-BcII with imipenem (red line) or Co(II)-BcII with imipenem (blue line). Absorption units are arbitrary and not indicated. 
The $380 \mathrm{~nm}$ band can thus be taken as an indication of formation of an anionic intermediate, partially resembling the $407 \mathrm{~nm}$ band attributed to $\mathrm{EI}^{1}$ (blue trace in Figure 7). A stopped-flow experiment performed by mixing imipenem with $\mathrm{Zn}$ (II)-BcII revealed the development of an absorption band at $380 \mathrm{~nm}$ during the first 10 $\mathrm{ms}$ of the reaction (see red line overlaid in Figure 7 and also see S11 in Supporting Information) that closely resembles the one generated by proton abstraction. Taken together, these results strongly support that imipenem hydrolysis by BcII proceeds through formation of a deprotonated form of a ring-opened pyrrolidine derivative.

To further confirm this hypothesis DFT-based calculations for the possible intermediate structure were performed. The same calculations were done for the substrate, the product, and a neutral intermediate (protonated at $\mathrm{N}-1$ ). The results indicate that the intermediate species is negatively charged on both the $\mathrm{N}-1$ and $\mathrm{C}-3$ atoms of the five-membered ring. The $\mathrm{N}-1 / \mathrm{C}-2$ and $\mathrm{C}-2 / \mathrm{C}-3$ bond distances are intermediate between single and double bonds, suggesting formation of a delocalized $\mathrm{n}$ system encompassing the $\mathrm{N}-1$ and C-3 atoms (Figure S8, Supporting Information). Frequency calculations predicted an isolated Raman intense stretching frequency of $1615 \mathrm{~cm}^{-1}$ for this species (Figure S8A, Supporting Information), which is in good accord with the $1541 \mathrm{~cm}^{-1}$ experimental band found in the resonance Raman experiment, especially if we bear in mind that the DFT B3LYP/6-31G** calculated frequencies tend to be slightly overestimated. ${ }^{42}$ This band corresponds almost exclusively to the C2-C3 stretching. The other species showed mixtures of less intense bands in this region. The calculated absorption spectrum for this intermediate bound to a Co(II) ion is predicted to show a transition at $399.5 \mathrm{~nm}$ that can be assimilated to the notorious $407 \mathrm{~nm}$ feature of $\mathrm{EI}^{1}$. The other investigated species are predicted to display electronic transitions at lower wavelenghts (Figure S8B, Supporting Information). While these calculations support the feasibility of the proposed intermediate, a more detailed QMMM approach including the protein would be required to gain a better description of the geometric features of $\mathrm{EI}^{1}$.

If our conclusions on the nature of the intermediate were correct, we could expect the same kind of intermediate being formed

Journal of the American Chemical Society, Vol 130, No. 47 (November 26, 2008): pg. 15852-15863. DOI. This article is (C) American Chemical Society and permission has been granted for this version to appear in e-Publications@Marquette. American Chemical Society does not grant permission for this article to be further copied/distributed or hosted elsewhere without the express permission from American Chemical Society. 
during hydrolysis of other carbapenems, which share the characteristic pyrrolidine ring with imipenem. To prove this hypothesis, we carried out a similar experiment with the substrate meropenem. As shown in Figure 8 (right panel), the reaction proceeded with formation of a very similar intermediate with a strong absorption at $407 \mathrm{~nm}$.
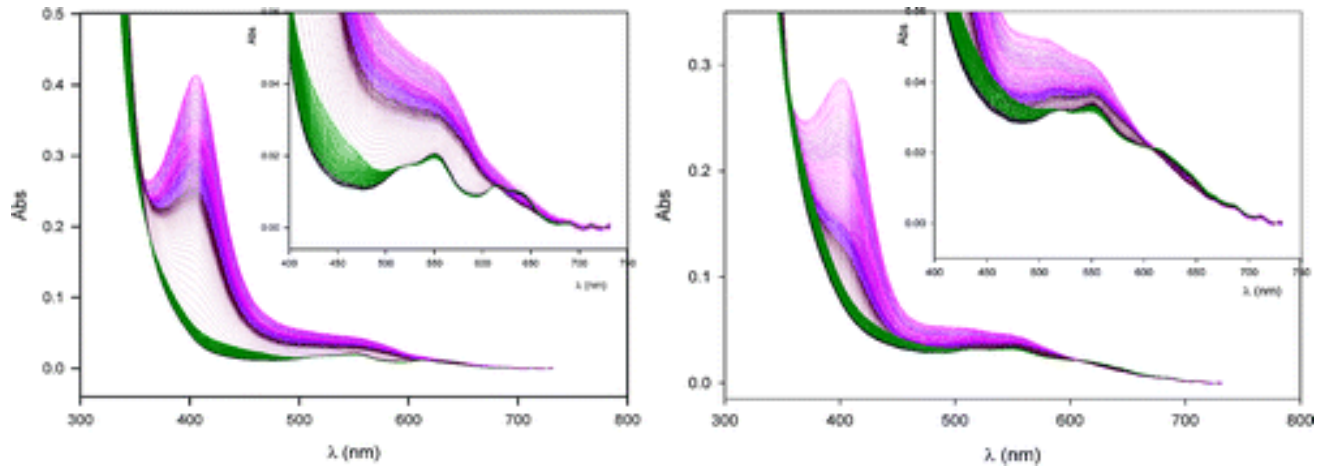

Figure 8. Electronic absorption spectra of di-Co(II) BcII during hydrolysis of imipenem and meropenem. (Left) Hydrolysis of imipenem ([BcII] $=83 \mu \mathrm{M} ;[\mathrm{Co}(\mathrm{II})]=166 \mu \mathrm{M}$; [imipenem] $=2500 \mu \mathrm{M})$. The reaction was carried out at $6{ }^{\circ} \mathrm{C}$ in a stopped-flow system associated with a photodiode-array detector. (Right) Hydrolysis of meropenem $([\mathrm{BcII}]=62.5 \mu \mathrm{M} ;[\mathrm{Co}(\mathrm{II})]=200 \mu \mathrm{M}$; [meropenem $]=250 \mu \mathrm{M})$. The reaction was carried out at $16^{\circ} \mathrm{C}$ in a stopped-flow system associated with a photodiode-array detector. In both cases, the spectra were recorded on a logarithmic base with an integration time of $1.28 \mathrm{~ms}$. The shown spectra correspond to $50 \mathrm{~s}$ following mix of enzyme and substrate, and they progress from pink to green. Insets show a magnification of the $400-750 \mathrm{~nm}$ region.

This signal is almost identical to that detected for imipenem despite exhibiting subtle differences in the ligand field region of the spectrum. Also, the accumulation and decay rates are different according to the distinct turnover rates for each substrate. This experiment allows us to generalize our conclusions and suggest that the metal-stabilized, negatively charged intermediate of hydrolysis is common to all carbapenems.

\section{Discussion}

Mechanism-based strategies for inhibitor design have proved successful for the most widespread class of serine- $\beta$-lactamases. ${ }^{43,44}$ These enzymes hydrolyze the $\beta$-lactam ring using an activated hydroxyl from a Ser residue, which gives rise to a covalent acyl-enzyme intermediate. ${ }^{1}$ This tetrahedral intermediate is stabilized by an oxyanion hole, resembling the intermediate in serine proteases mechanism. Some $\beta$-lactam compounds such as clavulanic acid, 
sulbactam, and tazobactam act as "suicide inhibitors" because they can bind to the enzyme, react to form the covalent tetrahedral intermediate, but then rearrange in the active site and resist subsequent deacylation. ${ }^{45}$ Carbapenems act as both antibiotics inactivating their bacterial targets and at the same time inhibitors for serine- $\beta$-lactamases of classes $A$ and $C$. As for the case of the other $\beta$ lactamase inhibitors, carbapenems can give rise to a tetrahedral acyl-enzyme intermediate that resists deacylation and permanently inactivates the $\beta$-lactamase. ${ }^{28}$

Metallo- $\beta$-lactamases rely on a completely different reaction mechanism and not only resist inhibition by carbapenems but also hydrolyze them very efficiently. MßLs lack a defined oxyanion hole and employ an attacking nucleophile arising from a water molecule (that might be metal activated or not), which is not covalently bound to the enzyme. ${ }^{4}$ This explains the resistance displayed by these enzymes to the $\beta$-lactam inhibitors mentioned above and at the same time justifies the lack of evidence for a long-lived tetrahedral intermediate in $\mathrm{M} \beta \mathrm{L}-$ mediated hydrolysis. ${ }^{13,19,20,46-48}$ A kinetically trapped intermediate has been reported for hydrolysis of the chromophoric cephalosporin nitrocefin. ${ }^{19,20}$ Benkovic and co-workers have shown that this is an anionic intermediate with a negatively charged nitrogen stabilized by interaction with the $\mathrm{Zn}$ (II) ion in the $\mathrm{DCH}$ site in the $B$. fragilis enzyme CcrA (a B1 enzyme). 19,20 Later, McManus-Munoz and Crowder characterized a similar intermediate for the B3 lactamase L1 from $S$. maltophilia. ${ }^{23}$ These experiments suggested that a negatively charged nitrogen coordinated to this metal site could be exploited as a transition-state analogue. However, nitrocefin (apart from being a nonclinically useful antibiotic) differs from most $\beta$-lactams in possession of an extended $\Pi$-conjugated system that stabilizes this anionic species, somehow limiting generalization of this finding. ${ }^{48}$

Here we report the characterization of a novel intermediate in the hydrolysis of imipenem and meropenem by BcII in which the $\beta$ lactam ring has already been cleaved. A reaction intermediate with a strong absorption feature at $407 \mathrm{~nm}\left(\mathrm{EI}^{1}\right)$ is observed during imipenem hydrolysis by $\mathrm{Co}$ (II) BcII at different $\mathrm{Co}(\mathrm{II}) / \mathrm{BcII}$ ratios. A branched kinetic scheme (Scheme 1) including different metallated species accounts for the observed kinetic behavior. RFQ-EPR 
experiments show different spectral changes when imipenem is mixed with $\mathrm{CO}_{0.5}-\mathrm{BcII}$ and di-Co(II) BcII. The EPR spectrum of $\mathrm{CO}_{0.5}-\mathrm{BcII}$ with imipenem corresponds to a dominant $S=3 / 2$ signal followed by almost complete reversion to the resting signal, providing strong evidence that at least one monometallated form of the enzyme is active. EPR data on di-Co(II) BcII show changes in the parallel mode, confirming that the integer-spin dinuclear site in BcII is also active. An EP complex is formed with imipenem, which is considered in Scheme 1.

The intense absorption band at $407 \mathrm{~nm}$ is shifted to $380 \mathrm{~nm}$ when imipenem is hydrolyzed by $\mathrm{Zn}$ (II)-BcII, confirming involvement of the metal center in the stabilization of this species. When hydrolyzed imipenem (which has undergone a $\Delta^{2}$ to $\Delta^{1}$ tautomerization) is deprotonated, an anionic species with similar features is formed, suggesting that the accumulated intermediate has a negative charge in the $\mathrm{C}-3$ atom. The RFQ-RR experiment unequivocally shows that the $407 \mathrm{~nm}$ band is associated with an enzyme-bound species with a $\mathrm{C}=\mathrm{C}$ or $\mathrm{C}=\mathrm{N}$ distorted bond. The proposed structure of the putative intermediate was optimized by quantum mechanical calculations, which resulted in complete agreement with a species with a highly delocalized charge over a conjugate system involving the $\mathrm{N}-1$ and $\mathrm{C}-3$ atoms of the fivemembered ring.

Figure 9 shows a cartoon describing the interaction of the proposed intermediate with the metal site. This species has a $n-$ delocalized resonant structure that could account for the UV-vis and resonance Raman properties of the intermediate $\mathrm{EI}^{1}$. This anionic intermediate could be stabilized by the metal ion resembling a $n-$ cation interaction. The difference in the position of the absorption maxima when the reaction is performed with $\mathrm{Co}$ (II) or $\mathrm{Zn}$ (II)-BcII confirms direct involvement of the metal ion in this intermediate. The intermediates that accumulate during hydrolysis by mono-Co(II) or diCo(II) BcII present similar electronic absorption features. This suggests that the metal ion in mono-Co(II) BcII is located in the DCH site, which is the only one capable of interacting with the substrate carboxylate and the $n$ system of the negatively charged fivemembered ring. This conclusion is in excellent agreement with that 
arising from independent data on penicillin $G$ hydrolysis in that substrate binding shifts the equilibrium between the mono- $\mathrm{Co}$ (II) $\cdot 3 \mathrm{H}$ and mono-Co(II).DCH species to the second one.

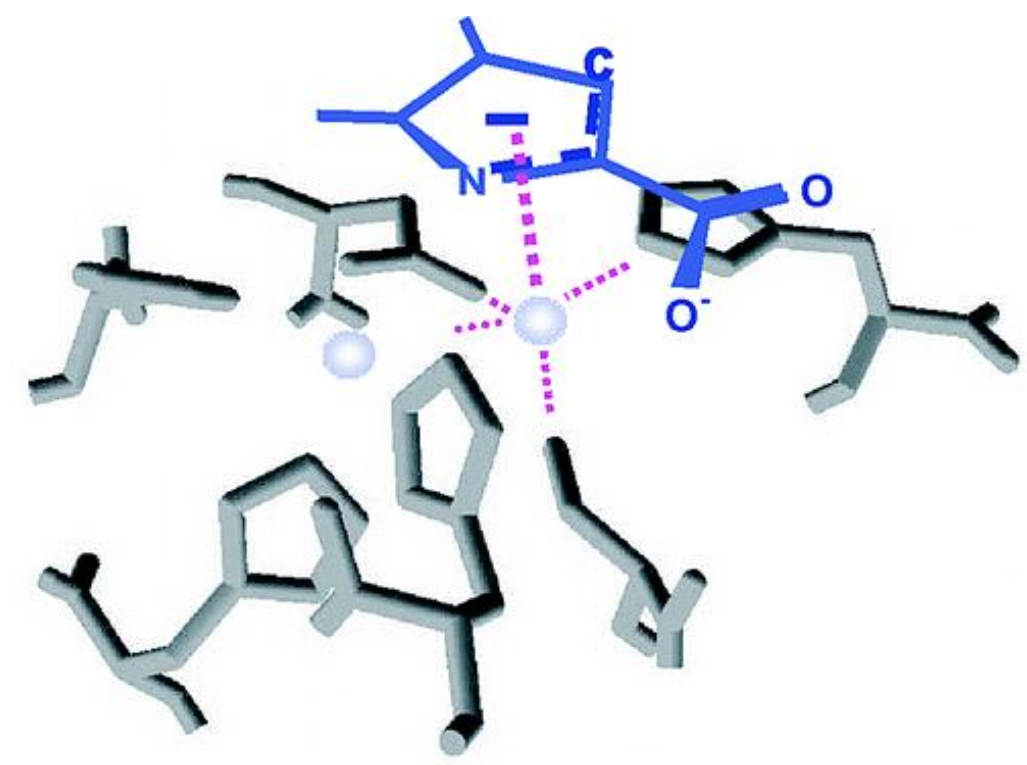

Figure 9. Schematic representation of the proposed structure of the main intermediate $\mathrm{EI}^{1}$.

The chemical nature of this intermediate also provides a plausible mechanistic explanation for the branching point included in the model (Scheme 1) purely based on kinetic data, as shown in Scheme 3. Substrate binding to the enzyme relies mainly on contacts between the $\mathrm{C}-2$ carboxylate, the metal ion at the $\mathrm{DCH}$ site, and residue Lys224. This metal-carboxylate interaction has been proposed to occur either by direct binding or mediated by a water molecule. ${ }^{54}$ Our data do not allow us to distinguish between these two proposals, which are equally suitable to the herein proposed mechanism. After substrate positioning the $\beta$-lactam carbonyl is attacked by an activated water molecule, rendering an opened ring derivative with a net negative charge, delocalized over a conjugated $n$ system encompassing atoms $\mathrm{N}-1$ and $\mathrm{C}-3$. This anionic species $\left(E I^{1}\right)$ is stabilized by direct interaction with the metal ion. $\mathrm{EI}^{1}$ can follow two possible pathways: (a) it can protonate at $\mathrm{N}-1$ giving tautomer $\Delta^{2}$, which once released to the aqueous millieu tautomerizes rapidly to its $\Delta^{1}$ form, giving a mixture of the a and $\beta$ diasteromers, or (b) it can remain inside the enzyme pocket, which would favor localization of the negative charge on $\mathrm{C}-3\left(\mathrm{EI}^{2}\right) . \mathrm{EI}^{2}$ would then be protonated 
stereospecifically, giving rise to an enzyme-product adduct ( $\mathrm{EI}^{3}$ or $E P)$. In this way, this model gives an interpretation to the branching point in the kinetic scheme and also accounts for the partial stereoselectivity observed in the reaction of BcII with imipenem.

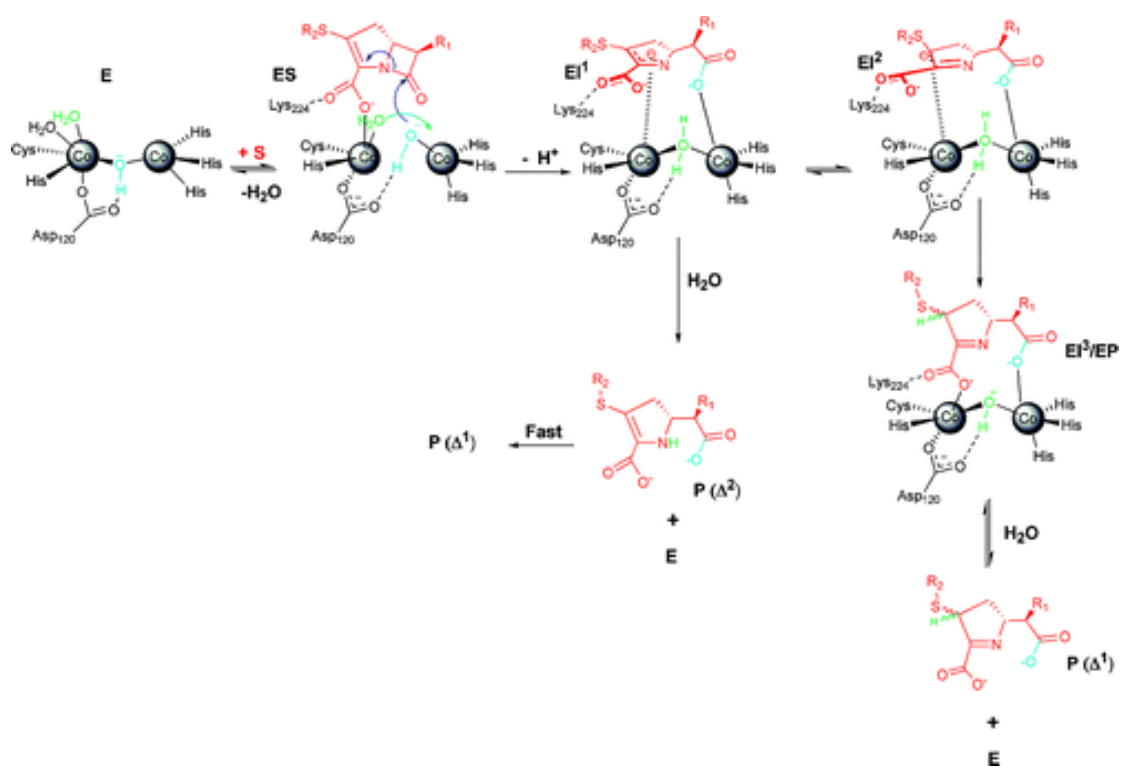

Scheme 3. Proposed Reaction Mechanisma

a Note: While the $\mathrm{Zn}$ (II) ion at the DCH site is pentacoordinate as indicated by the crystal structure, Co(II) would be hexacoordinate according to spectroscopic data. This difference can be accounted for by binding of a second water molecule to the Co(II) ion at this site, as shown in $\mathrm{E}$.

These findings provide novel insights into the roles of the metal ions in BcII that can be generalized to all MBLs. A recent theoretical study ${ }^{49}$ suggested that the nucleophilic water molecule in the B2 MBLs is activated by a metal-liganding oxygen atom of a carboxylate rather than directly by a $\mathrm{Zn}$ (II) ion; an analogous mechanism was proposed for the B3 lactamase GOB from E. meningoseptica ${ }^{26}$ and for another metallohydrolase, aminopeptidase from Vibrio, on the basis of crystallographic and EPR spectrokinetic studies. ${ }^{50}$ The latter study, in particular, highlighted the role of the metal center in activating substrate, proposing that as the primary role for the metal center rather than nucleophile activation and delivery.

According to the model here proposed the metal ion in the $3 \mathrm{H}$ site would activate the nucleophile water molecule in the dinuclear enzyme. We propose that such a function is carried out by a net of hydrogen-bond interactions with protein residues in the case of the 
mononuclear enzyme that would only bear a metal ion in the $\mathrm{DCH}$ site (possible residues being His118 or Asp120, as proposed for the class B2 CphA lactamase). In this way, catalysis would directly involve the metal ion in the DCH site for both the mono- and dinuclear enzymes, and this proposal would account for the similarities observed in the electronic spectra of the mononuclear and dinuclear intermediates. The finding of similar intermediates in mono- and dinuclear species with different attacking nucleophiles can be accounted for by the observation that nucleophilic attack is not rate limiting in any studied MBL-catalyzed reaction. This is valid for dinuclear B1 and B3 enzymes ${ }^{10,19,23,53}$ as well as for the mononuclear B2 enzyme ImiS, which lacks a metal-activated nucleophile. ${ }^{12}$

The mechanism proposed for the Co(II) enzyme can be extended to the native $\mathrm{Zn}$ (II) form based on the chemical properties of both ions, as discussed in the preceding paper. In addition, here we observed an intermediate accumulating during the reaction of $\mathrm{Zn}$ (II)-BcII with imipenem, which exhibits the same features as the deprotonated product, i.e., a broad absorption centered at $380 \mathrm{~nm}$ (Figure 7). Furthermore, the finding of a similar intermediate species for two carbapenems suggests that this intermediate is not imipenem specific but most probably characteristic of carbapenems in general.

Here we have shown that imipenem hydrolysis by BcII occurs via accumulation of an anionic intermediate that is stabilized by the metal ion at the DCH site. The particular chemical nature of this intermediate suggests a new hypothesis for designing $M \beta L$ inhibitors, targeted to the $\mathrm{Zn} 2$ site, in line with recent evidence of the key role of this center. ${ }^{51-53}$ This represents a novel, previously unforeseen intermediate that is related to the specific chemical nature of carbapenems. According to this view, failure to form or accumulate such an intermediate species in penicillin $\mathrm{G}$ or cefotaxime hydrolysis is based on the impossibility of these substrates to develop a $\Pi$ conjugated system for delocalization of the emerging negative charge.

Despite the fact that this intermediate has not been observed in B2 or B3 enzymes, it should be noted that carbapenems are the only substrates in common for B1, B2, and B3 lactamases and they all share a $\mathrm{DCH}$ or $\mathrm{DHH}$ site with a similar role in the catalytic 
mechanism. Thus, identification of this intermediate in the hydrolysis pathway could be exploited as a first step toward the design of transition-state-based inhibitors for B1 enzymes and possibly extended to other subclasses.

\section{Acknowledgment}

This work was supported by grants from ANPCyT and HHMI to A.J.V. D.H.M thanks the financial support by ANPCYT and CONICET. The NMR spectrometer was purchased with funds from ANPCYT (PME2003-0026) and CONICET. L.I.L. and A.A.P. are recipients of doctoral fellowships from CONICET. A.J.V., E.G.M., M.A.M., D.H.M., and M.F.T. are Staff members from CONICET, and A.J.V. is also an International Research Scholar of the Howard Hughes Medical Institute. EPR and RFQ work was supported by the NIH AI056231 and EB001980 to B.B. The authors thank Jason Kowalski for his help with the EPR experiments.

\section{Supporting Information}

Fits of traces at 640 or $407 \mathrm{~nm}$ to different possible kinetic models; electronic absorption spectra of E and EP; simulation of species accumulation under the conditions of RFQ-EPR reactions; computed absorption spectra using TD-DFT and predicted Raman spectra and geometric parameters of the calculated structures; electronic absorption spectra of di-Co(II) BcII during hydrolysis of $100 \mu \mathrm{M}$ imipenem; analysis of the steps in the reaction of $\mathrm{Co}$ (II)-BcII as evidenced by stopped flow data; stopped-flow experiment of di-Zn(II) BcII with imipenem; complete ref 36 . This material is available free of charge via the Internet at http://pubs.acs.org.

\section{References}

${ }^{1}$ Fisher, J. F., Meroueh, S. O., and Mobashery, S. Chem. Rev. 2005105395 424

2Frere, J. M. Mol. Microbiol. 199516385395

${ }^{3}$ Perez, F., Endimiani, A., Hujer, K. M., and Bonomo, R. A. Curr. Opin. Pharmacol. 20077459469

${ }^{4}$ Crowder, M. W., Spencer, J., and Vila, A. J. Acc. Chem. Res. 200639721 728

${ }^{5}$ Walsh, T. R., Toleman, M. A., Poirel, L., and Nordmann, P. Clin. Microbiol. Rev. 200518306325

${ }^{6}$ Bebrone, C. Biochem. Pharmacol. 20077416861701

7Hall, B. G., Salipante, S. J., and Barlow, M. J. Mol. Evol. 200357249254

${ }^{8}$ Galleni, M., Lamotte-Brasseur, J., Rossolini, G. M., Spencer, J., Dideberg, O., and Frere, J. M. Antimicrob. Agents Chemother. 2001453660663 
NOT THE PUBLISHED VERSION; this is the author's final, peer-reviewed manuscript. The published version may be

accessed by following the link in the citation at the bottom of the page.

${ }^{9}$ Hernández Valladares, M., Felici, A., Weber, G., Adolph, H. W., Zeppezauer, M., Rossolini, G. M., Amicosante, G., Frère, J. M., and Galleni, M.

Biochemistry 1997361153411541

${ }^{10}$ Sharma, N. P., Hajdin, C., Chandrasekar, S., Bennett, B., Yang, K. W., and Crowder, M. W. Biochemistry 2006451072910738

${ }^{11}$ Costello, A. L., Sharma, N. P., Yang, K. W., Crowder, M. W., and Tierney, D. L. Biochemistry 2006451365013658

${ }^{12}$ Crawford, P. A., Yang, K. W., Sharma, N., Bennett, B., and Crowder, M. W. Biochemistry 20054451685176

${ }^{13}$ Garau, G., Bebrone, C., Anne, C., Galleni, M., Frere, J. M., and Dideberg, 0. J. Mol. Biol. 2005345785795

${ }^{14}$ Felici, A., Amicosante, G., Oratore, A., Strom, R., Ledent, P., Joris, B., Fanuel, L., and Frère, J. M. Biochem. J. 1993291151155

${ }^{15}$ Paul-Soto, R., Bauer, R., Frere, J. M., Galleni, M., Meyer-Klaucke, W., Nolting, H., Rossolini, G. M., de Seny, D., Hernandez-Valladares, M., Zeppezauer, M., and Adolph, H. W. J. Biol. Chem. 199927413242 13249

${ }^{16}$ Paul-Soto, R., Hernandez Valladares, M., Galleni, M., Bauer, R., Zeppezauer, M., Frere, J. M., and Adolph, H. W. FEBS Lett. 1998438137140

${ }^{17}$ Wommer, S., Rival, S., Heinz, U., Galleni, M., Frere, J. M., Franceschini, N., Amicosante, G., Rasmussen, B., Bauer, R., and Adolph, H. W. J. Biol. Chem. 20022772414224147

${ }^{18}$ Orellano, E. G., Girardini, J. E., Cricco, J. A., Ceccarelli, E. A., and Vila, A. J. Biochemistry 1998371017310180

${ }^{19}$ Wang, Z., Fast, W., and Benkovic, S. J. Biochemistry 1999381001310023

${ }^{20}$ Wang, Z., Fast, W., and Benkovic, S. J. J. Am. Chem. Soc. 199812010788 10789

${ }^{21}$ Spencer, J., Clarke, A. R., and Walsh, T. R. J. Biol. Chem. 200127633638 33644

${ }^{22}$ Ullah, J. H., Walsh, T. R., Taylor, I. A., Emery, D. C., Verma, C. S., Gamblin, S. J., and Spencer, J. J. Mol. Biol. 1998284125136

23McManus-Muñoz, S., and Crowder, M. W. Biochemistry 19993815471553

${ }^{24}$ Mercuri, P. S., Garcia-Saez, I., De Vriendt, K., Thamm, I., Devreese, B., van Beeumen, J., Dideberg, O., Rossolini, G. M., Frere, J. M., and Galleni, M. J. Biol. Chem. 20042793363033638

${ }^{25}$ Garrity, J. D., Bennett, B., and Crowder, M. W. Biochemistry 2005441078 1087

${ }^{26}$ Moran-Barrio, J., Gonzalez, J. M., Lisa, M. N., Costello, A. L., Peraro, M. D., Carloni, P., Bennett, B., Tierney, D. L., Limansky, A. S., Viale, A. M., and Vila, A. J. J. Biol. Chem. 20072821828618293

${ }^{27}$ Nukaga, M., Abe, T., Venkatesan, A. M., Mansour, T. S., Bonomo, R. A., and Knox, J. R. Biochemistry 2003421315213159

Journal of the American Chemical Society, Vol 130, No. 47 (November 26, 2008): pg. 15852-15863. DOI. This article is (C) American Chemical Society and permission has been granted for this version to appear in e-Publications@Marquette. American Chemical Society does not grant permission for this article to be further copied/distributed or hosted elsewhere without the express permission from American Chemical Society. 
NOT THE PUBLISHED VERSION; this is the author's final, peer-reviewed manuscript. The published version may be accessed by following the link in the citation at the bottom of the page.

${ }^{28}$ Beadle, B. M., and Shoichet, B. K. Antimicrob. Agents Chemother. 200246 39783980

${ }^{29}$ Bertini, I., and Luchinat, C. Adv. Inorg. Biochem. 1985671111

${ }^{30}$ Periyannan, G. R., Costello, A. L., Tierney, D. L., Yang, K. W., Bennett, B., and Crowder, M. W. Biochemistry 20064513131320

${ }^{31}$ Breece, R. M., Costello, A., Bennett, B., Sigdel, T. K., Matthews, M. L., Tierney, D. L., and Crowder, M. W. J. Biol. Chem. 200528011074 11081

${ }^{32}$ Llarrull, L. I., Tioni, M. F., Kowalski, J., Bennett, B., and Vila, A. J. J. Biol. Chem 20072823058630595

${ }^{33}$ Hunt, J. B., Neece, S. H., and Ginsburg, A. Anal. Biochem. 1985146150 157

${ }^{34}$ Kuzmic, P. Anal. Biochem. 1996237260273

${ }^{35}$ de Seny, D., Heinz, U., Wommer, S., Kiefer, M., Meyer-Klaucke, W., Galleni, M., Frere, J. M., Bauer, R., and Adolph, H. W. J. Biol. Chem. 2001276 4506545078

${ }^{36}$ Frisch, M. J.; et al. Gaussian 03; Gaussian, Inc.: Wallingford, CT, 2004.

${ }^{37}$ Bicknell, R., Schaeffer, A., Waley, S. G., and Auld, D. S. Biochemistry 1986 2572087215

${ }^{38}$ Totir, M. A., Helfand, M. S., Carey, M. P., Sheri, A., Buynak, J. D., Bonomo, R. A., and Carey, P. R. Biochemistry 20074689808987

${ }^{39}$ Ratcliffe, R. W., Wildonger, K. J., Dimichele, L., Douglas, A. W., Hajdu, R., Goegelman, R. T., Springer, J. P., and Hirshfield, J. J. Org. Chem. 198954653660

40Zafaralla, G., and Mobashery, S. J. Am. Chem. Soc. 199211415051506

${ }^{41}$ Taibi, P., and Mobashery, S. J. Am. Chem. Soc. 199511776007605

${ }^{42}$ Levine, I. N. Quantum Chemistry, 5th ed.; Prentice Hall: New York, 1999.

${ }^{43}$ Sulton, D., Pagan-Rodriguez, D., Zhou, X., Liu, Y., Hujer, A. M., Bethel, C. R., Helfand, M. S., Thomson, J. M., Anderson, V. E., Buynak, J. D., Ng, L. M., and Bonomo, R. A. J. Biol. Chem. 20052803552835536

${ }^{44}$ Bush, K. Clin. Microb. Rev. 19881109123

${ }^{45}$ Imtiaz, U., Billings, E. M., Knox, J. R., and Mobashery, S. Biochemistry 1994 3357285738

${ }^{46}$ Bounaga, S., Laws, A. P., Galleni, M., and Page, M. I. Biochem. J. 199831 703711

47McManus-Munoz, S., and Crowder, M. W. Biochemistry 199938154753

${ }^{48}$ Spencer, J., Clarke, A. R., and Walsh, T. R. J. Biol. Chem. 200127633638 33644

${ }^{49}$ Xu, D., Xie, D., and Guo, H. J. Biol. Chem. 200628187408747

${ }^{50}$ Kumar, A., Periyannan, G. R., Narayanan, B., Kittell, A. W., Kim, J. J., and Bennett, B. Biochem. J. 2007403527536

${ }^{51}$ Gonzalez, J. M., Medrano Martin, F. J., Costello, A. L., Tierney, D. L., and Vila, A. J. J. Mol. Biol. 200737311411156 
NOT THE PUBLISHED VERSION; this is the author's final, peer-reviewed manuscript. The published version may be accessed by following the link in the citation at the bottom of the page.

${ }^{52}$ Llarrull, L. I., Fabiane, S. M., Kowalski, J. M., Bennett, B., Sutton, B. J., and Vila, A. J. J. Biol. Chem. 20072821827618285

${ }^{53}$ Crisp, J., Conners, R., Garrity, J. D., Carenbauer, A. L., Crowder, M. W., and Spencer, J. Biochemistry 2007461066410674

${ }^{54}$ Dal Peraro, M., Vila, A. J., Carloni, P., and Klein, M. L. J. Am. Chem. Soc. 200712928082816

${ }^{55}$ Llarrull, L. I., Tioni, M. F., and Vila, A. J. J. Am. Chem. Soc. 2008, 130, 15842-15851, preceeding paper in this issue.

Journal of the American Chemical Society, Vol 130, No. 47 (November 26, 2008): pg. 15852-15863. DOI. This article is (C) American Chemical Society and permission has been granted for this version to appear in e-Publications@Marquette. American Chemical Society does not grant permission for this article to be further copied/distributed or hosted elsewhere without the express permission from American Chemical Society. 